\title{
Turkey and the Arab Revolutions: Boundaries of Regional Power Influence in a Turbulent Middle East
}

\section{Ziya Öniş"}

The recent Turkish involvement in the Middle East constitutes an important test case for establishing the boundaries of regional power influence in a changing global context. The AKP government in Turkey has become a major supporter of political change and democratization in the era of the Arab revolutions. Accumulating empirical evidence suggests, however, that the highly assertive and pro-active foreign policy of the AKP government in recent years has not been effective in terms of facilitating reform or regime change in Syria or helping to influence the direction of political change in Egypt towards a durable pluralistic order. Indeed, the policy might have been counter-productive in terms of undermining Turkey's image of a benign regional power, by drawing it to sectarian conflicts and overengagement in the domestic politics of key Arab states. Turkey has the potential to play an important role model in the highly uncertain world of the Arab revolutions. Its ability to perform this role, however, requires an improvement in its own democratic credentials, rather than being excessively involved in the domestic politics of individual states.

\section{Introduction}

The onset of the 'Arab Spring' in the early months of 2011 brought a new wave of optimism to a region distinguished by its highly entrenched authoritarian regimes. Indeed, the literature had often referred to 'Middle East exceptionalism' to highlight the resilience of authoritarian structures to successive waves of democratic opening, which deeply affected other parts of the world (Bellin, 2004). The wave of revolutions in the Arab world has generated a process of dramatic change, raising considerable optimism concerning the future of political

\footnotetext{
* Correspondence Address: Professor Ziya Öniş, Department of International Relations, Koç University, Rumelifeneri Yolu, Sarıer, Istanbul, Turkey 34450, Email: zonis@,ku.edu.tr
} 
liberalization in the region (Bayat, 2013). At least, a process of change has been set into motion, which will be difficult to reverse in the coming years. Well-established autocratic leaders of the region such as Qaddafi in Libya, Mubarak in Egypt and Ben Ali in Tunisia have been ousted from power. What has also been exciting about the Arab Spring is that it has largely been an internally driven process (Hollis, 2012) -a movement from below- with the active engagement of the public at large in facilitating a process of momentous political change.

Yet, looking at the political landscape of the region after some two and half years following the onset of the 'Arab Spring', it is increasingly hard to sustain the early optimism. Whilst the impetus for change has been quite remarkable, the persistence and resilience of authoritarian structures has also been equally striking, generating considerable disillusionment with the degree of progress accomplished so far. The Syrian case is perhaps the most dramatic example of how an authoritarian political leader such as Basher el-Assad has been able to hold on to power, in spite of massive resistance from societal forces, resulting in a severe human tragedy (Lesch, 2013). The Egyptian case is also quite striking in the sense that the country's first democratic experiment with an elected government has ended, at least for the moment, with a military coup, pushing the democratically elected Mohammed Morsi and the Muslim Brotherhood out of power. In Libya, the post-Qaddafi situation looks highly uncertain, with significant polarization among different segments of society. Tunisia is perhaps the only case where significant and durable steps have been taken towards political liberalization. One should also add that there are large parts of the Arab world, notably Saudi Arabia and the Gulf countries have proved to be quite impervious to any kind of political opening. They, in fact, openly supported the military coup in Egypt. Whilst some scholars continue to employ the term 'Arab Spring' (Dabashi, 2012), it is increasingly more common to characterize the process of dramatic change as 'Arab uprisings' (Gelvin, 2012) or 'Arab revolution(s)' (Filiu, 2011; Lynch, 2012). The term 'Arab revolutions' may be a more appropriate term to use in the present context to highlight that the current transformations involve a radical change of a far-reaching and long-term nature. At the same time, it is a more complicated, open-ended and reversible process than most analysts had originally anticipated. Furthermore, the term 'revolutions' rather than 'revolution' per se may be appropriate to underline the fact that national experiences in the Arab world are likely to display considerable variations over time.

Turkey's foreign policy activism in the Middle East during the last decade constitutes an interesting debate regarding the limits of regional power influence. Flemes (2007) suggests 
regional powers are defined with reference to four major criteria: the claim to leadership, possession of the necessary power resources, employment of successful foreign policy strategies, and acceptance of leadership role by other states in the region (also see Prys, 2010). The objective of this essay is to examine the role of Turkey, as an increasingly assertive regional power in recent years, in the context of the on-going and the highly uncertain process, described as the 'Arab revolutions.' Especially, during the later phase of the Justice and Development Party (the AKP) government, the Middle East and North Africa became a focal point of Turkish foreign policy (Altunışık and Martin, 2011; Aras and Polat, 2007; Oğuzlu, 2008; Öniş and Yılmaz, 2009). With Ahmet Davutoğlu, in the driving seat, Turkey has increasingly positioned itself as a key player in the region based on its soft power (Aras, 2009; Öniş, 2012b). The Turkish experience during the course of the Arab revolutions is quite illuminating, from a broader comparative perspective, in highlighting the limits of middle power influence especially through unilateral activism, in a region where both global powers such as the United States, Russia and China as well as rival regional powers such as Saudi Arabia, Iran and Israel are very much present and where politics is complicated not only by rivalries among different states, but also by profound ethnic and sectarian divisions (Ayoob, 2012). Contrary to the initial expectations of key policy elites, Turkey's ability to influence the path of political change in the Middle East has so far proved to be quite limited. Indeed, the over-activism of Turkish foreign policy has generated significant criticism both in the domestic circles and on the part of the wider international community. Turkey appears to have been drawn into the perennial sectarian conflicts, such as the Sunni-Shiite rivalry and its overactivism, especially in the Syrian case, has raised concerns about the revival of neo-imperial reflexes, raising the charge of 'neo-Ottomanism' (Öktem et al. 2012; Tuğal, 2012). Similarly, Turkey's engagement has been rather one-sided, with strong and unequivocal support for the Muslim Brotherhood at the expense of other segments of the Egyptian society. These elements clearly come into conflict with the vision of a 'benign regional power' attempting to promote change in the region through a combination of economic interdependence, cultural affinity and active democracy promotion through its soft power capabilities.

\section{Turkish Foreign Policy toward the Middle East in the pre-Arab Spring Era: Economy, Security and Identity Nexus}

The pro-active and multi-dimensional foreign policy of the AKP era might be conceptualized in terms of the security-economy and identity nexus. From an interest-based and statecentered perspective, economy and security considerations were central driving forces in the 
'zero problems with neighbors strategy' popularized by Ahmet Davutoğlu, as the advisor to the Prime Minister Recep Tayyip Erdoğan and subsequently to the Foreign Minister Abdullah Gül in the early years of the AKP and as the Foreign Minister himself in later years of the AKP from May 2009 onwards.

During the first phase of the AKP, corresponding to the 2002-2007 era, EU membership was the prime reference point of Turkish foreign policy. At the same time, a concerted effort was made to diversify Turkey's external relations and to improve relations with all neighboring countries. Indeed, the origins of this multi-dimensional foreign policy and rapprochement process involving countries like Greece and Syria pre-date the AKP era. Important progress had been achieved under the coalition government of the 1999-2002 era, with Ismail Cem, a social democratic politician, in charge of foreign policy (The Economist, 2000). Nevertheless, the process continued and gathered additional momentum during the AKP era. The period was characterized by a striking improvement in relations with Russia, Iran and Syria. The rapprochement with Syria was quite striking, given that the bilateral relations between the two countries had been quite tense and conflict-driven throughout the 1990s (Tür, 2011; Hinnebusch and Tür, 2013).

Ultimately, security and economic concerns are intrinsically interlinked. Clearly, there was a desire on the part of the Turkish foreign policy making to create secure borders. Secure borders were important for stability in Turkey's domestic politics, given that key domestic problems such as the Kurdish conflict and the activities of the PKK had a strong transnational dimension. Secure borders were also a necessity for expanding trade, investment, labor flows, tourism and other forms of economic linkages, which were clearly beneficial for the Turkish economy, which displayed a considerable degree of stability and dynamism, compared to the 1990s (Öniş, 2012a). Indeed, a virtuous cycle was created with greater security along the borders and growing economic interdependence between Turkey and the neighboring regions tending to reinforce to create a mutually beneficial process. Growing economic interdependence was also important given the essential complementarities between the economies of Turkey and its key neighbors, with Turkey having the edge in producing consumer goods and engaging in construction activities, in return for oil and natural gas from its neighbors given its perennial problem of energy dependence. The conception of Turkey as a 'trading state' nicely captures the on-going dynamic laying the basis of Turkey's rediscovery of its neighborhood during this period (Kirişçi, 2009; Kutlay, 2011). 
The process of diversification in Turkey's external relations was not a purely state-driven process. The growing strength and diversification of Turkish business was also at the heart of this process (Öniş, 2012a; Kutlay, 2011). A striking feature of this period involved the rise and internationalization of the Anatolian capital, which constituted a major driving force in Turkey's growing links with all segments of its neighborhood, notably the Middle East and Africa. Indeed, key associations of private business in Turkey, institutions like TOBB, DEIK and TUSKON emerged as key non-state actors in Turkey's external diversification drive of the AKP era (Atl1, 2011; Öniş and Yılmaz, 2009). The global financial crisis of 2008-2009 and the ensuing stagnation in the European markets, Turkey's main trading partner, inevitably injected an additional momentum to this diversification process, as Turkey searched for new markets to make for the loss in EU trade. In 2003, the EU had accounted for 58 percent of Turkish exports, whilst the combined share of exports to Asia including the Middle and Near East and the North Africa had only constituted 14.9 percent. By 2012, the share of the exports to the EU had fallen to 38 percent, whilst the share of Asia including Middle and Near East and North Africa in Turkish exports had risen to 35 percent. Between 2002 and 2012, Turkey's exports to the Middle East increased from 3.4 to 42.4 billion dollars. Similarly construction projects realized by Turkish firms surpassed 183 billion dollars and overwhelming portion of these projects was conducted in the Middle East and North Africa (Öniş and Kutlay, 2013). Turkey also became an important donor country with its increasing role in development aid in neighbouring countries (Özkan and Demirtepe, 2012).

Economic and security considerations constitute important necessary conditions for accounting for the growing pro-activism of Turkish policy in the past decade with an explicit focus on different components of its neighborhood. Yet, they are not sufficient in terms of accounting for the depth of this diversification process. Identity considerations or 'civilizational geo-politics' are also crucial in terms of understanding the changing dynamics of Turkish foreign policy, notably its increasing focus on the Arab Middle East (Bilgin and Bilgiç, 2011; Aras and Polat, 2007). In this context, again several elements were at work, with mutually reinforcing consequences. The first dimension involved the disappointments on the EU front, as the membership process reached a stalemate and the negotiation process experienced a deadlock, due to an inherent failure to agree on a mutually acceptable solution to end the Cyprus dispute. During the later phase of the AKP decade, namely the post-2007 period, the EU was no longer the prime reference point of Turkish foreign policy. What we observe during the second phase of the AKP is the continuation and intensification of the 
multi-dimensional foreign policy and the impetus to diversify Turkey's external relations, but in the absence of a firm EU anchor.

The growing emphasis on the Middle East and the broader neighborhood was also significantly shaped and facilitated by dramatic shifts in the existing power relations in the sphere of domestic politics. Key actors in Turkish politics such as the military and the Kemalist bureaucracy including the foreign policy establishment progressively lost their dominant status in the center of the Turkish politics, as the AKP increasingly acquired a hegemonic position in the Turkish political system. The natural consequence of these power shifts was that Western orientation no longer constituted the overriding element in Turkish foreign policy. The AKP, as a post-Islamist party with a powerful religious-conservative core was better placed to engage with the Muslim world, compared with its predecessors, namely key elements of the secular, Kemalist establishment. With the rising tide of conservatism and a rediscovery of the Ottoman past in Turkish politics (Çarkoğlu and Kalaycıoğlu, 2009), it was perhaps inevitable that the Muslim world, in general, and the Arab world, in particular, would occupy a central stage in Turkish foreign policy, a process driven not only by mutual economic interests but also by common identity based on cultural affinity.

The AKP during its later phase positioned itself not as a typical candidate country of the EU, acting collectively for common policy goals, but as a kind of independent regional power in the Middle East, drawing its strength from mutual economic interests and common Muslim identity. What was also striking in the pre-Arab spring context is that democracy promotion was not on the AKP's policy agenda. Indeed, the AKP's basic message was that Turkey was willing to develop strong relations with key Middle Eastern states as equal partners on grounds of economic interests and a common cultural heritage. There was no explicit reference to democracy promotion or regime transformation. This approach which essentially involved an arm's length relationship, respecting the sovereign space of domestic politics in existing Arab regimes, allowed the AKP elites to form strong relations with several authoritarian rulers in the region, notably al-Assad in Syria and Qaddafi in Libya, a situation which was destined to change dramatically with the onset of the Arab revolutions during the early months of 2011.

\section{Turkey's Response to the Arab Revolutions: between Grand Strategy and Pragmatism}

Turkish policy makers faced a major dilemma with the onset of the Arab revolutions. Strong bilateral relationship had been established with countries like, Syria, Egypt and Libya, based 
on a Westphalian understanding of state sovereignty. This understanding had allowed flourishing relations to develop with highly authoritarian states, whose results have been lucrative in economic terms with significant benefits in the realms of trade, investment and tourism. Taking a pro-democracy position and providing active support for popular resistance to the established regimes may jeopardize Turkey's important economic interests in the region. At the same time, continuing to support the existing regimes at a time of great popular resistance would undermine Turkey's ambitions to play a regional leadership role and diminish its credentials to serve as a role model for countries, which for the first time enjoyed a great opportunity to dismantle authoritarian regimes and replace them with open and competitive political systems. This kind of ethics versus interest dilemma was not unique to Turkey. The United States and the European Union were confronted with a similar challenge. Europe, in particular, whilst championing democracy promotion in rhetoric as part of its neighborhood policy, nevertheless had for a long time continued to engage and sustain significant economic relations with a number of highly entrenched and brutal authoritarian regimes in the region, of which Tunisia, Egypt, Morocco as well as Qaddafi's Libya constituted striking examples (Dinçer and Kutlay, 2013).

Whilst the AKP leadership embraced the turn to democracy in the region right from the outset, its reluctance to translate this into concrete support for opposition movements in the early stages was quite evident from the lukewarm attitude towards intervention in Libya. Ultimately, Turkey joined the NATO coalition in Libya, but in a rather passive role, in a process led by the European powers, Britain and France, with significant support from the United States. Turkey was reluctant to engage in Libya given the depth of Turkish investment in the country. Moreover, the AKP leadership was reluctant to target a Muslim country. Furthermore, Qaddafi was also a leader with whom the AKP leadership and the Prime Minister Erdoğan, in particular, had managed to forge strong personal ties in the past, providing yet another justification for reluctance to be actively involved in the NATO initiative in this particular instance.

The AKP leadership became increasingly aware, however, that the passive or lukewarm attitude towards popular uprisings would undermine Turkey's popularity in the region. As a result, a shift towards a stronger and more vocal support by the Turkish government to the regime transformation process in Egypt and Syria could be discerned as the Arab Spring continued to unfold during the course of 2011. In the Egyptian case, the AKP elites welcomed the collapse of the Mubarak regime and endorsed the attempts to institute steps in the 
directions of an open political system based on elections and a new constitution. Over time, the AKP became vocal in support for the Muslim Brotherhood, especially once its position as the dominant political faction was formally endorsed in the first democratically held elections in the country (Ahramonline, 2013).

In the Syrian case, the AKP clearly wanted to play an even more active role, first in the direction of political reform within the parameters of the existing al-Assad regime and once this solution proved to be unworkable, changing course and promoting regime transformation by active support to the opposition forces. The first two years of the Arab revolutions clearly highlighted the dilemmas raised by Turkey's grand ambitions to play a pro-active leadership in the region and the structural limits imposed on its power in a turbulent region where major global and regional powers have also been actively engaged, effectively limiting the space that any single regional power could exploit through independent or quasi-independent action (Kardaş, 2013). As a result, the pendulum has been swinging back and forth between episodes where Turkey tried to lead events, which was clearly the case in the quest to try to force alAssad from power in the Syrian context. Similar instances could be discerned in turns of vocal criticisms of Israel and the championing of the Palestinian cause, instances where Turkish policy clearly deviated from the position of the United States.

One could also detect other cases, however, Turkish position has been more subdued and where Turkey has clearly indicated its desire to be a partner of United States and the Western security alliance, as the fault-lines between the Western powers and countries like Iran and Russia became more obvious in the new Cold War context emerging in the age of the Arab revolutions (Martin, 2013). The latter tendency is quite evident in the context of the conflict involving the Western powers and Iran over the nuclear arms issue. In the pre-Spring era, Turkey attempted to adopt a more independent approach to the dispute indicated by its desire to play a neutral broker role together with Brazil. More recently, however, Turkey has been more firmly placed in the Western camp and has not been on the frontline of countries involved in the dispute over the Iran's nuclear program. A similar pattern is evident in the context of Turkish-Israeli relations, which experienced an unexpected turn for improvementthough clearly not on the scale of the military-strategic relations of the 1990s -especially following the apology by the Israeli political establishment concerning the dispute over the Mavi Marmara incident. This event again demonstrated the influence of the Obama administration and the pressure exerted by the United States to keep both Turkey and Israel in the orbit of the Western alliance. The recent Turkish-Israeli rapprochement is also related to 
the substantial offshore gas finds in Eastern Mediterranean, which offers a novel sphere for co-operation.

These observations suggest that there exists an inherent tension between Turkey's desire to play an ambitious role in the region in line with Davutoğlu's grand vision of Turkey as a key regional power based on its 'strategic depth' (Davutoğlu, 2013), which rightly or wrongly carries with neo-Ottomanist overtones and a more cautious and pragmatic approach which tends to recognize the limitations of Turkey's economic and diplomatic capacity. What the era of the Arab revolutions so far has demonstrated is not only the limits on Turkey's ability to play a grand leadership role, but also the inherent adaptability and pragmatism of Turkish foreign policy in line with the changing external circumstances.

\section{Syria as a Test Case of Turkish Foreign Policy: A Case of Failure}

Syria constitutes an important case study of the recent Turkish foreign policy in action. Arguably, Turkey has been more actively engaged in Syria than any other Arab country in the context of the on-going Arab revolutions. The policy towards Syria clearly highlights some of the broader generalizations made concerning the limits and contradictions of the grand strategy and regional leadership ambitions, on the one hand, and adaptability and pragmatism in line with changing circumstances on the other. Two important limitations of Turkey's policy towards should be identified from the outset, however. First, Turkey's efforts to play a leading role in terms of instigating regime change in Syria have hitherto failed to generate the desired impact. Secondly, Turkey, as a consequence of its over-activism in Syria and overinvolvement in Syrian domestic politics has been drawn, perhaps quite unintentionally, into sectarian conflicts. This, in turn has aggravated its relations with key regional powers like Iran and the central government in Iraq, whilst at the same time undermining its positive image in the region.

The relations between Turkey and Syria had improved steadily in the post-1999 period. Prior to the onset of the Arab revolutions, the relations had reached a climax. The golden age of the relations between the two countries was marked by rapidly expanding trade as well as significant human interaction, as the elimination of visa restrictions involved a large flow of people across the border. The two leaders, Tayyip Erdoğan and Basher al-Assad were on extremely friendly terms. Turkey during this period presented itself as a gateway for Syrian integration to the global market. Clearly, the Turkish approach, based on a mixture of economic and cultural interaction, did not present any problems for the existing Syrian regime. 
Certainly, the Turkish policy-makers did not make any reference to democratization at this point. They might have contemplated the idea that with greater economic openness and large movement of people across the border would have positive repercussions in terms of bringing about stage by stage political liberalization in the longer-run. Even if the architects of Turkish foreign policy such as Davutoğlu entertained this kind of vision, it was never openly pronounced.

The onset of the Arab uprisings and their spread to Syria naturally had a traumatic effect on bilateral relations. Once Turkey changed course and started to actively embrace the discourse of democratization for the region, this inevitably entailed a heads on clash with the Assad regime. Having been side-lined in Libya, the AKP leadership wanted to play a more active role in the neighboring Syrian context. The initial reaction was to put pressure on the Assad regime to undertake political reforms, based on the expectation that the strength of the personal ties between Erdoğan and al-Assad would provide a crucial leverage for Turkey to play a constructive role in Syria's political opening without actually necessitating a change of the existing regime. Once this approach proved to be futile and Assad started to wage a brutal war against the opposition forces, Turkish policy towards Syria changed course quite dramatically. From that point of onwards, the AKP government openly declared its opposition to the Syrian regime and its support for the opposition forces. Not only did Turkey provide support to the opposition forces, but also it became a major champion of a possible initiative to engineer a multilateral humanitarian intervention to end the civil war in Syria, similar to the earlier NATO-based initiative in Libya.

Turkey during this period also supported a major humanitarian effort to accommodate large exodus of refugees from Syria flying from the atrocities of the Syrian government forces. By June 2013, about 580 thousand Syrian refugees were accommodated in Turkey along the Syrian border. The Turkish approach to Syria in the context of Arab revolutions presented a marked contrast to the previous era. Erdoğan's statement that 'Syria is Turkey's internal affair' aptly summarizes the new approach, which sharply differed from the approach that characterized the earlier era, namely respect for sovereignty of domestic politics of a neighboring country. Turkey's Syria policy was driven by both humanitarian and ethical considerations and also by real politik. The AKP leadership had a clear desire to influence the course of future political developments in Syria, especially taking into the fact that the Syrian Kurds would emerge as an important element of a future political order, with natural repercussions for Turkey's own Kurdish problem, in the sphere of domestic politics. The fact 
that the AKP emerged victorious from the general elections of June 2011 with almost 50 percent of the vote meant that the party leadership could comfortably shift its attention away from domestic political concerns and pursue a pro-active foreign policy in Syria and the Middle East in general with renewed vigor and self-confidence.

In retrospect, Turkey's recent Syrian policy was based on a series of miscalculations. Firstly, Erdoğan over-estimated its leverage on Assad, based on the strength of the personal ties and the depth of the economic and cultural ties established during the golden age period. Secondly, the Turkish policy-makers under-estimated the resilience of the Ba'athist establishment and over-estimated the capacity of the opposition forces to mount a major challenge to the existing message. The AKP leadership believed that the Assad regime would inevitably crumble after a few months in the face of mounting opposition and growing international pressure from the West. This perception, however, failed to account the transnational links of the Syrian regime, especially from Iran which saw the Assad as a bulwark of Shiite influence in the Arab Middle East and Russia, for which the Syrian regime was a natural ally and gateway to the rest of the Middle East. Finally, Turkish policy-makers failed to recognize the reluctance of the international community, especially the Obama administration in the United States to engage in yet another costly intervention, with negative memories of the earlier wave of interventions in Afghanistan, Iraq and Libya. Even in the case of Libya where there to be stronger consensus for intervention at the international level, what appeared to be an unambiguously positive outcome initially was later counterbalanced by the intensification of polarization and instability in the post-Qaddafi era, once again raising question marks against the inherent merits of humanitarian interventionism.

The result of this over-activism has been to bring growing security risks for Turkey in its southern border, without necessarily augmenting its position as a key actor in resolving the Syrian crisis. Indeed, a cursory examination of the recent peace initiatives to try to resolve the Syrian crisis in the context of the on-going Geneva talks point towards the United States and Russia as key actors, with Turkey occupying a marginal role, certainly not a position in line with what the AKP leadership intended to project in the first instance. On balance, the AKP leadership was justified in adopting a strongly pro-democratizing posture and subjecting the Assad regime to severe criticism for the brutal consequences of its actions. Moreover, Turkey tried to play a constructive, humanitarian role in accommodating a large group of refugees escaping from the civil war. 
Beyond this, however, Turkish foreign policy was open to criticism for excessive involvement in Syria's internal politics and treating Syria's domestic conflict as if it was part of Turkey's own internal politics. Moreover, in this result this kind of over-interventionist stance has brought few tangible benefits in terms of resolving the crisis, but has been quite costly in terms increasing security risks for Turkey and undermining Turkey's image as a neutral power-broker in the region (International Crisis Group, 2013). On the refugee issue, one could add another criticism that Turkey has been unable to convert its commendable unilateral effort to a genuine multilateral effort. Arguably, a greater willingness to co-operate with the international community, notably with the EU and the UN in running the refugee camps together, would render Turkey's contributions more visible on an international scale and would also have been useful in terms of sharing the material burden of maintaining a sizable community of refugees destined to stay on the Turkish side of the border for an indefinite time period.

Turkish foreign policy towards Syria should not be criticized for failing to end or finding a durable solution to the Syrian crisis. Turkey as a 'regional power' clearly does not have the capacity to achieve the results that 'great powers' like the United States, China and Russia have so far failed to accomplish. The key failing has been due to the fact that Turkey has over-engaged itself in Syria, contributing to further instability and undermining both its own interests and international image in the process.

\section{The Costs of Over-engagement: Turkey as a Regional Power drawn into Sectarian Conflicts}

Critiques of recent Turkish foreign policy have drawn attention to the fact that the Turkey is positioning as the champion of Sunni Islam in the Middle East and, hence, drawn into sectarian conflict in the context of one of the great fault lines in Middle Eastern politics, namely the Sunni-Shiite divide (Tuğal, 2012). It is argued that this is a natural outgrowth of the AKP championing Sunni Islam in the sphere of Turkey's own domestic politics, which so far have provided limited space for accommodating the demands of its own Alawite minority. A natural consequence of this tendency is to contribute to further instability in key states affected by the spread of the Arab revolutions. Ironically, therefore, Turkey, in spite of its original claims to act as a benign regional power, is likely to play a destabilizing rather than a stabilizing role in the region. 
It is hard to accept that Turkey is intentionally promoting Sunni Islam in the region as part of its grand strategy for regional leadership. Certainly, an examination of Turkish foreign policy during the AKP era as a whole would not lend support to this proposition. The underlying logic of the AKP's foreign policy approach was to develop close relations with the Muslim world as a whole rather than its constituent parts. A key element in this scenario involved playing a possible leadership role for the Muslim world in relations with the wider world, notably with the West and the EU, in particular, through schemes such as the Dialogue of Civilizations Initiative (Öniş and Yılmaz, 2009). Furthermore, developing friendly relations with Iran, as opposed to seeing it as a natural and inevitable competitor in the Middle East, constituted a central thrust of Turkish foreign policy during the AKP era. Indeed, as indicated earlier, Turkey had actively tried to play a neutral broker role in the conflict between Iran and West over the development of Iran's nuclear program. Certainly, the AKP government has been more receptive to the idea of developing close diplomatic and political relations, going beyond concerns of economic interests and interdependence, compared to any other Turkish government in the past.

Yet, there is evidence to support the claim that Turkey is siding with Sunni Muslims in a number of on-going conflicts within the key Arab States. This appears to be the case in Syria where active support for the opposition involves support for the Sunni elements against the Shiite regime of Basher al-Assad, which, in turn, is closely supported by Iran. In Iraq, to the outrage of the US leadership, Turkey seems to be increasingly engaged with the semiautonomous Kurdish Administration in Northern Iraq and other Sunni elements in Iraq, whilst increasingly alienating the Maliki government in Baghdad in the process. In the Egyptian context, a similar tendency is apparent given the strong support by the AKP to the Muslim Brotherhood at the expense of other groups within the country's broad political coalition. Consequently, Turkey has found itself in the awkward position of being part of the Sunni axis in the Middle East represented by countries like Saudi Arabia and Qatar, with established authoritarian regimes, which so far have been quite resilient to the spread effects of the Arab revolutions. Being drawn into this kind of coalition on sectarian lines is highly inconsistent with Turkey's image as force for democracy promotion in the Arab world.

Our central hypothesis is that this negative tendency is an unintended consequence of excessive involvement in the domestic politics of key Arab states rather than the outcome of an explicit grand strategy or policy design. The problem is that the AKP leadership has been taking sides in domestic disputes on the basis of insufficient knowledge and expertise about 
domestic politics of Arab states with the natural corollary of not being able to anticipate the potentially negative consequences of such actions (Dinçer and Kutlay, 2013). The case with the Muslim Brotherhood in Egypt constitutes a clear case where the AKP has provided unequivocal support for Muslim Brotherhood and President Morsi, in spite of the fact that the policies pursued by Muslim Brotherhood in office have led greater polarization in Egypt, paving the way for the military coup of July 2013. The AKP government may be justified in voicing its criticisms of the military coup. Yet, it certainly failed to adopt a balanced and inclusive approach, which took into account the concerns of wide segments, especially the secular segments of the Egyptian society, when the Brotherhood was actually in power (Dinçer and Farhoqui, 2013). Indeed, prior to the military coup one could detect certain parallels between the majoritarian understanding of democracy of the AKP and Morsi's uncompromising attitude towards the opposition in the process of drawing up a new constitution, which would accommodate the demands of the different strands of the opposition. Certainly, the AKP, in principle, could have played a more constructive role in the Egyptian context whilst where a balanced line of support for the Muslim brotherhood would be accompanied by advice in the direction of compromise and consensus and the need to accommodate the demands of the opposition groups, especially the secular groups, in designing a mutually acceptable constitutional process.

\section{Explaining Over-engagement in the Middle East: The Interactions between Domestic Politics and Foreign Policy}

Domestic politics and foreign policy are intrinsically interrelated. In the recent Turkish context, the arrow has moved in both directions. First, foreign policy has become an important tool for the AKP to consolidate and extend its popular support on the domestic front. Second, the over-concentration of power at the new 'center' of Turkish politics, the absence of effective opposition from the center-left and Turkey's continuing democratic deficits (Öniş, 2013) have also contributed to an over-ambitious foreign policy strategy, whose limitations have already been identified, particularly not only in the case of Syria, but also in the Iraqi and Egyptian contexts.

There is no doubt that the AKP leadership has effectively capitalized upon a highly assertive and a more independent line of foreign policy with an explicit focus on the Arab Middle East. This kind of policy was clearly based on Turkey's rising self-confidence during the AKP era, 
a process that was clearly supported by rising economic dynamism. Turkey during the AKP era displayed impressive rates of economic growth. In the presence of improved fiscal discipline and financial regulation, Turkey managed to avoid the kinds of perennial stop and go cycles and the inevitable encounter with the IMF, which was a striking characteristic of the 1990s. Indeed, the country managed to pull through during the period of a global financial crisis without a single bank failure and the need to sign an agreement with the IMF, at a time when several Euro-zone countries, notably Greece as well as several Southern and East European countries found themselves in the midst of severe crises and dislocations with extremely negative economic and political consequences. Economic dynamism was at the heart of a newly acquired self-confidence. The AKP leadership was confident that Turkey would be able to play increasingly active role on a regional as well as the global level. The Prime Minister Erdoğan's increasingly vocal posture, for example championing the Palestinian cause and taking tough position against Israel, at the cost of jeopardizing a wellestablished relationship, appeared to pay handsome dividends not only in the Arab streets, but also in the Turkish streets among large segments of the Turkish public.

The underlying logic of the AKP's foreign policy was based on a new kind of nationalism, a nationalism with conservative and religious overtones, yet outward-oriented and globalist in its orientation (Öniş, 2012a; Kadığlu and Keyman, 2009). Among vast segments of the AKP electorate, this policy seemed to contrast sharply with the timid and exclusively Westernoriented policy stance of the traditional foreign policy elites. It was only more recently when Turkey's over-activism on the Syrian front started to generate some genuine security risks for Turkish people living in the border towns like Hatay, with the much-publicized Reyhanlı incident, that the policy started to generate vocal criticism and resentment in the realm of Turkey's domestic politics. Twin car bombs went off in the town center in the Turkish town of Reyhanlı on the Syrian border resulted in the murder of at least 51 people in May 2013. The attack on Reyhanl, home to thousands of Syrian refugees and a gathering point for rebels fighting to topple President al-Assad, amplified the fears that the Syrian conflict had moved to Turkey. Indeed, the Reyhanlı incident showed that the Syrian crisis indeed became part of Turkish domestic politics, but through quite different route then what Prime Minister Erdoğan had originally in mind, namely through causing increasing security risks for Turkish citizens located right across the Syrian border.

Turning to the other side of the coin, the excessive power acquired by the AKP over the course of three successive electoral victories, also effectively bolstered the self-confidence of 
key foreign policy figures like Erdoğan and Davutoğlu. By the time of the third phase of the AKP government, pertaining to the post-2011 period, there was hardly any effective position to the dominant foreign policy-making core within the AKP. The traditional, Kemalist foreign policy establishment has been effectively side-lined in line with the profound shifts of power taking place in Turkish politics, as the AKP increasingly moved to the very center of Turkish politics. Similarly, a radical reordering of civil-military relations meant that the military no longer occupied the pivotal place in Turkish foreign policy. Another striking shift was within the AKP itself. The liberal elements, which were important components of the AKP's broad based coalition, including the core religious-conservatives as well Turkish and Kurdish nationalists, appeared to be progressively marginalized and side-lined during the later years of the AKP decade. Hence, the foreign policy vision of the core group represented by Davutoğlu and Erdoğan could be implemented without any mechanism of checks and balances. Arguably President Gül appeared to play a balancing role in foreign policy. However, he was no longer a member of the core group and, hence, in the driving seat of the foreign policy as in the early days of the AKP era, when he was actually the Foreign Minister.

An equally important element in this context proved to be the inability of the principal opposition parties, notably the Republican People's Party (the CHP), to mount effective opposition and play a balancing role in foreign policy. The weakness of the CHP in the foreign policy field became particularly obvious when the leadership adopted a rather lukewarm position towards the Arab Spring as opposed to a consistent line of support for the democratization agenda. The divisions within the party between the liberals and nationalists were also reflected in the realm of foreign policy. Whilst the liberal segments were, on the whole, more positive in their attitudes towards the Arab revolutions, the nationalists and hardline Kemalists adopted a more ambivalent stance. For the latter group, the main concern was the rise of Political Islam, which often meant that they were willing to show tolerance for the persistence of authoritarian regimes on the grounds that such regimes would help to sustain secular political systems whose very foundations would be eroded once the Islamists acquired power through the ballot box. There is a fine line to be drawn between questioning the democratic credentials of the Islamists in power, which clearly applies to the case of Egypt, and denying political space to the Islamists altogether. To be fair, the CHP leadership tried to make a case for a more cautious line of foreign policy towards the region. However, given the perennial divisions within the party, it could not present a coherent alternative vision, which was sensitive to the problems of democratization and regime change in the region, but 
which would also avoid the pitfalls of over-engagement in the region, in the domestic politics of countries such as Syria, Iraq and Egypt with potentially negative and destabilizing consequences.

\section{Concluding Observations}

The changing global order provides new opportunity spaces for rising regional powers to play more pro-active roles at global and regional levels. The present analysis suggests that regional powers, indeed, have the potential to make an impact (Öniş and Kutlay). However, it also suggests the space available to regional powers to make a dramatic impact in their regions, through more independent and unilateral forms of action, in key areas such as regime transformation and the resolution of on-going bilateral conflicts, may not be as wide as some scholars or policy-makers might have initially assumed.

Turkey in the context of the Middle East, in general, and the case of Syria, in particular, constitutes an important test case for identifying the boundaries of regional power influence in a changing global context. Accumulating empirical evidence suggests that the highly assertive and pro-active foreign policy of the AKP government in recent years has not been effective in terms of facilitating regime change in a key neighboring country Syria. Indeed, the policy might have been counter-productive in terms of undermining Turkey's image of a benign regional power, by drawing it to sectarian conflicts and over-involvement in the domestic politics of key Arab states, hence raising deep question marks about respect for national sovereignty in the process. This inference does not imply that the alternative approach would be to remain totally indifferent to a deep human strategy such as the Syrian crisis, which is located at its very border. Turkey certainly played an important and constructive role in terms of humanitarian aid and welcoming massive numbers of Syrian refugees from the other side of the border. Similarly, the criticism of the brutal atrocities of the Assad regime is also perfectly legitimate. The question is where we draw the boundaries of humanitarian interventionism and whether supporting the opposition directly in the midst of an on-going armed conflict is justifiable on ethical grounds as well on the country's own security interests.

The present paper highlights a central paradox relating to the boundaries of regional power influence. A country like Turkey can make a real impact on its neighboring regions by serving point of reference through its level of economic development and quality of its democratic 
governance. In the Middle Eastern context, this impact can be even more striking given that the rival regional powers like Saudi Arabia and Iran are authoritarian states. The more it is engaged in the domestic politics of the individual states in the region, the more it is likely to jeopardize its own soft power and attractiveness as a role model. A natural corollary of this proposition is that Turkey's ability to play this kind role model for the region will depend crucially on its ability to overcome its own democratic deficits, which are quite significant as the recent wave of popular protests in Taksim Square known as 'Gezi protests', and the authoritarian response to these protests on the part of the AKP government clearly demonstrate. The AKP government displayed a great deal of sensitivity in its reactions to the military coup in Egypt and has been quite critical of the EU leaders for not being equally critical and responsive. However, this kind of sensitivity and pro-democratization posture adopted towards events in the outside world are not likely to generate international attention and credibility, given the widespread belief that Turkey's democratic credentials display a number of important deficiencies and Turkey itself falls short of establishing a genuinely pluralistic political order with unambiguous recognition and respect for diversity.

Finally, the existence of clear limits on the constructive impact of unilateral activism clearly points towards the importance of co-operative action through multilateral channels. For example, Turkey's impact in terms of facilitating regime transformation in the region would be significantly enhanced if it could actively co-operate with the EU, as a candidate country and as a potential member, as opposed to a country which is organizing its foreign policy on the basis of a series of bilateral relationships and reluctantly adopting itself to multilateral action, once unilateral activism clearly failed, as it was the case in putting pressure on alAssad to step down. The EU may not appear to be an attractive partner in the current conjuncture due to its own on-going economic and identity crisis. In the medium-term, however, a strengthening of the Turkey-EU partnership will be critical if Turkey indeed wants to present itself as a key democracy promotion force in the region.

\section{Acknowledgements}

Earlier versions of the paper have been at seminars and conferences at Stanford, Tilburg, Oxford, Koç and the Middle East Technical University. The author would like to thank participants at those meeting as well as Mustafa Kutlay, Erdem Demirtaş, Selim Erdem Aytaç and Mustafa Yağcı for their valuable criticisms and Mertcan Özer for his able assistance. The constructive comments and criticisms of three anonymous referees of the Journal are gratefully acknowledged. 


\section{References}

Ahramonline (2013) Morsi ouster in Egypt dents Turkey role model claims, Available at http://english.ahram.org.eg/NewsContent/2/(/75818/World/Region/Morsi-ouster-in-Egyptdents-Turkey-role-model-clai.aspx (accessed 15 June 2013).

Altunışık, M. \& Martin, L. G. ( 2011) Making sense of Turkish foreign policy in the Middle East under AKP, Turkish Studies, 12(4) , pp. 569-587.

Aras, B. (2009) Turkey's rise in the Greater Middle East: peace-building in the periphery, Journal of Balkan and Near Eastern Studies, 11(1), pp. 29-41.

Aras, B. \& Polat, R. K. (2007) Turkey and the Middle East: frontiers of the new geographic imagination, Australian Journal of International Affairs, 61(4), pp. 471-488.

Atl1, A. (2011) Businessmen as diplomats: the role of business associations in Turkey's foreign economic policy, Insight Turkey, 13(1), pp. 109-128.

Ayoob, M. (2012) The Arab Spring: its geostrategic significance, Middle East Policy, 19(3), pp. 84-97.

Bayat, A. (2013) The Arab Spring and its surprises, Development and Change, 44(3), pp. 587601.

Bellin, E. (2004) The robustness of authoritarianism in the Middle East: exceptionalism in comparative perspective, Comparative Politics, 36(2), pp. 139-157.

Bilgin, P. \& Bilgiç, A. (2011) Turkey’s 'new' foreign policy towards Eurasia, Eurasian Geography and Economics, 52(2), pp. 173-195.

Çarkoğlu, A. and Kalaycıoğlu, E. (2009) Rising Tide of Conservatism in Turkey (New York: Palgrave and Macmillan).

Dabashi, H. (2012) The Arab Spring: The End of Post-colonialism ( London: Zed Books).

Davutoğlu, A. (2013) The three major earthquakes in the international system and Turkey, The International Spectator, 48(2), pp. 1-11. 
Dinçer, O. B. \& Farhoqui, F. (2013) 'Kapsayıcı' anlayıştan ‘dışlayıcı' yaklaşıma? Yeni Misır'da Türkiye algıs1, Bilig (forthcoming).

Dinçer, O. B. \& Kutlay, M. (2013) The Arab Spring: a game changer in Turkey-EU relations? Perspectives on European Politics and Society, $i$-first version, Available at http://www.tandfonline.com/doi/pdf/10.1080/15705854.2012.753701 (accessed 12 June 2013).

Filiu, J. P. (2011) The Arab Revolution: Ten lessons from the Democratic Uprising (Oxford and New York: Oxford University Press).

Flames, D. (2007) Conceptualising regional power in international relations: Lessons from the South African case, GIGA Working Paper No. 53.

Gelvin, J. L. (2012) The Arab Uprisings: What Everyone Needs to Know (London and New York Oxford University Press).

Hinnebusch, R. and Tür, Ö.,eds., (2013) Turkey-Syria Relation. Between Enmity and Amity (London: Ashgate).

Hollis, R. (2012) No friend of democratization: Europe's role in the genesis of the 'Arab Spring', International Affairs, 88(1), pp. 81-94.

International Crisis Group (2013) Blurring the borders: Syrian spillover risks for Turkey, Europe Report, No. 225.

Kadığlu, A. \& Keyman, F. (Eds) (2011) Symbiotic Antagonisms: Competing Nationalisms in Turkey (Salt Lake City: The University of Utah Press).

Kardaş, Ş. (2013) Turkey, a regional power facing the changing international system, Turkish Studies, forthcoming.

Kirişçi, K. (2009) The transformation of Turkish foreign policy: the case of the trading state, New Perspectives on Turkey, 40, pp. 29-57.

Kutlay, M. (2011) Economy as the 'practical hand' of 'new Turkish foreign policy': a political economy explanation, Insight Turkey, 13(1), pp. 67-88.

Lesch, D. W. (2013) The unknown future of Syria, Mediterranean Politics, 18(1), pp. 97-103. 
Lynch, M. (2012) The Arab Uprising: The Unfinished Revolutions of the Middle East ( New York: Public Affairs).

Martin, L. (2013) Turkey and the USA in a bipolarizing Middle East, Journal of Balkan and Middle Eastern Studies, 15(2), pp. 175-188.

Oğuzlu, T. (2008) The Middle Easternization of Turkey’s foreign policy: does Turkey dissociate from the West? , Turkish Studies, 9(1), pp. 3-20.

Öktem, K., Kadığlu, A. \& Karl1, M. (2012) Another Empire? A Decade of Turkey’s Foreign Policy under the Justice and Development Party (Istanbul: Istanbul Bilgi University Press).

Öniş, Z. (2012a) The triumph of conservative globalism: the political economy of the AKP era, Turkish Studies, 13(2), pp. 135-152.

Öniş, Z. (2012b) Turkey and the Arab Spring: between ethics and self-interest, Insight Turkey, 14(3), pp. 45-63.

Öniş, Z. (2013) Sharing power: Turkey's democratization challenge in the age of the AKP hegemony, Insight Turkey, 15(2), pp. 103-122.

Öniş, Z \& Kutlay, M. (2013) Rising powers in a changing global order: the political economy of Turkey in the age of BRICs, Third World Quarterly, 34(8), pp. 1409-1426.

Öniş, Z \& Y1lmaz, Y. (2009) Between Europeanization and Euro-Asianism: foreign policy activism in Turkey during the AKP era, Turkish Studies, 10(1), pp. 7-24.

Özkan, G \& Demirtepe, T. (2012) Transformation of a development aid agency: TİKA in a changing domestic and international setting, Turkish Studies, 13(4), pp. 647-664.

Park, B. (2012) Modern Turkey: People, State and Foreign Policy in a Globalised World (London: Routledge).

Prys, M. (2010) Hegemony, domination, detachment: Differences in regional powerhood, International Studies Review, 12(4), pp. 479-504.

Robins, P. (2013) Turkey's 'double gravity’ predicament: the foreign policy of a newly activist power, International Affairs, 89(2), pp. 381-397.

The Economist (2000) Ismail Cem: a Turkish Strategist. Feb $3^{\text {rd }}, 2000$, Available at http://www.economist.com/node/328977 (accessed 13 June 2013). 
Tuğal, C. (2012) Democratic janissaries? Turkey’s role in the Arab Spring, New Left Review, 76, pp. 5-24.

Tür, Ö. (2011) Economic relations with the Middle East under the AKP: trade, business community and reintegration with neighboring zones, Turkish Studies, 12(4), pp. 589-602.

White, J. (2013) Muslim Nationalism and the New Turks (Princeton, New Jersey: Princeton University Press). 